\title{
Child and family \\ characteristics as risk factors \\ for peer victimization in \\ kindergarten
}

\section{Sonja Perren, Stephanie Stadelmann and Kai von Klitzing}

The study was conducted at the Department of Child and Adolescent Psychiatry, University of Basel (Switzerland). The study was supported by the Swiss National Science Foundation (grant \# 32-66778.01), "Freie Akademische Gesellschaft Basel» and "Novartis-Stiftung".

The current study investigates whether children's difficulties (symptoms, verbal ability) mediate the impact of family variables (emotional family environment, parental education level and foreign citizenship) on peer victimization. Teachers and parents completed questionnaires; children completed the Berkeley Puppet Interview and a verbal ability test at the ages of 5 and $6(N=163)$. Results show that child and family characteristics independently of each other contribute to predict peer victimization. The higher are the level of conduct problems and emotional symptoms and the lower is the children's verbal ability, the higher is the frequency of victimization experiences. Children from families with low education level present an increased risk of victimization. Results are discussed regarding educational and clinical implications.

Bullying is a subtype of aggressive behaviour that is directed toward a specific victim. A child is usually defined as a victim of bullying when she/he is repeatedly harassed by peers over time (Olweus, 1991). Victims of bullying are not only at risk for a variety of mental health and adjustment problems, but are also at risk for school avoidance and academic difficulties (Graham, Bellmore \& Mize, 2006; Nishina, Juvonen \& Witkow, 2005).

Bullying is considered to be a social phenomenon, i.e., an aggressive pattern unfolding within specific social groups and contexts (Espelage \& Swearer, 2004; Pepler, Craig \& O’Connell, 1999). From a dynamic systems perspective (Pepler et al., 1999) the first steps toward the emergence of bullying are the cognitions, emotions, and behavior of bullies and victims. These personality patterns are influenced by family experiences, genetic factors, or by other systems such as siblings or peers. When a bully and a victim with certain cognitive and behavioral 
tendencies come face-to-face, interaction patterns may begin to emerge. In addition, the group, and the school level contribute to the development, acceleration, maintenance, and termination of bullying.

Therefore, some individual and family characteristics may increase children's vulnerability to be victimized. In the current study we consider individual child characteristics as proximal and family characteristics as distal risk factors regarding peer victimization. Specifically, we investigate whether children's difficulties mediate the impact of family variables on children's risk to be victimized in kindergarten.

\section{Child difficulties as risk factors for peer victimization}

There is a clearly established link between peer relationship problems and the development of psychopathology (Deater-Deckard, 2001; Hay, Payne \& Chadwick, 2004). Nevertheless, only little is known about whether peer problems contribute to the genesis of psychiatric disorders, or whether behavioural/emotional difficulties lead to peer problems. Hay et al. (2004) suggested that there is a reciprocal rather than a causal relationship between peer problems and emotional/behavioural difficulties from infancy to adolescence. In the current paper we investigate the impact of children's emotional and behavioural difficulties on peer victimization in kindergarten age.

As suggested by Hay et al. (2004) externalizing problems, internalizing problems and a lack of social skills contribute to negative peer relations. As peer rejection is considered as a risk factor for victimization (Hodges, Malone \& Perry, 1997), we might assume that the same risk factors operate regarding victimization. Two different pathways to victimization have been identified: aggressiveimpulsive behaviour and submissive-withdrawn behaviour (Alsaker \& Nägele, 2008). Hodges et al. (1999) found that over time internalizing (withdrawal, anxiety/depression, and hovering peer entry style) and externalizing (aggression, argumentativeness, dishonesty, pushy peer entry style, disruptiveness) behaviour problems contribute to victimization. Children who display both problem behaviours, i.e. aggressive/withdrawn children, suffer the highest levels of peer victimization (Ladd \& Burgess, 1999).

It has been suggested that in young children, externalizing behaviour patterns are more strongly associated with peer victimization than internalizing behaviour problems (Hanish \& Guerra, 2004). In a similar vein, developmental trends with regard to behavioural correlates of peer rejection have been identified: In kindergarten age (ages 4-7) social rejection was related to aggression, rule violations, hyperactivity, and disruptiveness; but there were only slight indications for the relation between social withdrawal and rejection (Coie, Dodge \& Kupersmith, 1990). In contrast to studies which mainly consider social withdrawal as indicator of internalizing problem behaviour, in our own studies we found rather strong associations between peer victimization and emotional problems 
(depressive-anxious symptoms) in kindergarten age (Perren, Von Wyl, Stadelmann, Burgin \& von Klitzing, 2006). Our findings correspond with studies indicating that children with depressive symptoms have poorer peer relations in terms of popularity, rejection or peer victimization (Henricsson \& Rydell, 2004; Rudolph \& Clark, 2001).

In sum, behavioural difficulties (conduct problems and hyperactive/impulsive behaviour) and emotional problems (depressive-anxious symptoms) may contribute to children's peer victimization.

\section{Family characteristics as risk factors for peer victimization}

The question about the role of family characteristics as a risk factor for bullying and victimisation has gained more and more attention in the last decades. It has been shown that there are several family variables which are linked to the development of bully/victim problems including parenting, emotional family environment, parental socio-economic status and immigrant background.

On the one hand, emotionally negative family interactions have been identified as risk factor for peer victimization. Several studies have shown that peer victimization is associated with inconsistent, punitive, hostile and/or abusive parenting, high negative expressiveness or high levels of family conflicts or violence (Bowers, Smith \& Binney, 1994; Burk et al., 2008; Finnegan, Hodges \& Perry, 1998; Ladd \& Ladd, 1998; Mohr, 2006; Rigby, 1993; Schwartz, Dodge, Pettit \& Bates, 1997; Stevens, De Bourdeaudhuij \& Van Oost, 2002). These findings mainly apply to the subgroup of aggressive victims. On the other hand, overprotection, intrusive parental involvement or intense closeness or cohesion has been discussed as potential risk factor for becoming (passive) victims of bullying mainly in boys (Bowers, Smith \& Binney 1992; Espelage, Bosworth \& Simon, 2000; Finnegan et al., 1998).

However, most of these studies did not take potential confounded (or mediating) variables into account. A multivariate approach might yield contradictory findings. For example Veenstra et al. (2005) found in their study comparing bullies, aggressive victims, victims and uninvolved children, that parental rejection, overprotection and emotional warmth in the family are not related to bullying and victimization when other factors such as familial vulnerability to externalizing and internalizing disorders and individual characteristics are controlled in the analyses.

In addition to negative parent-child interactions and parenting, children's family background has also been identified as risk factor for peer victimization. A comparative European study also showed that families' low socio-economic status is associated with higher levels of perceived peer victimization (von Rueden et al., 2006). Other studies have also shown that involvement in bullying as perpetrator or victim is more frequent in children and adolescents with a lower socio-economic bakkground (Veenstra et al., 2005; Wolke, Woods, Stanford \& Schulz, 2001). 
Several studies in Switzerland and Germany have shown that foreign children have a higher risk to be rejected by peers within their school classes (Eckhart, 2005; Kronig, Haeberlin \& Eckhart, 2000) or are more frequently victimized by their peers (von Grünigen, Perren, Nägele \& Alsaker, 2009). Other European and Anglo American Studies yielded similar results in regard to minority or ethnic background (Quintana et al., 2006; Ridder \& Dollase, 1999; Verkuyten, 2006). The question which remains open is why family characteristics such as low education or immigrant status have an impact on children's peer relations, i.e. what are the mediating mechanisms which explain the observed associations. For example, von Grünigen et al. (2009) found that children's local language competence (partially) mediates the impact of their families' immigrant background on peer acceptance and victimization.

\section{Research questions}

In the current paper we differentiate between proximal and distal risk factors for peer victimization. Child characteristics (emotional and behavioural difficulties, and verbal abilities) are considered as proximal risk factors: we assume that only when children with certain behavioural tendencies come face-to-face, is it possible for patterns of bullying to emerge (Pepler et al., 1999). In contrast, family characteristics (emotional family environment, parental educational level and foreign citizenship) are considered as distal risk factors which have an indirect impact on children's risk. In addition to the variables mentioned above, we will control for gender in the analyses.

First, we hypothesize that emotional symptoms, hyperactivity/impulsivity and conduct problems are positively associated with peer victimization. Second, we hypothesize that high levels of family conflicts are associated with higher levels of peer victimization. Third, we hypothesize that foreign language children and children from low educated families are more frequently victims of peer aggression.

Different modes of linkages between family and peer relationships have been suggested (Parke \& Ladd, 1992). One of the potential linkages is that experiences within their families shape children's behavioural patterns which in turn influence their peer relationships, i.e. children's competences and difficulties are considered as mediator between family and peer relationships. In the current study we assume that the impact of family characteristics on the risk to be victimized by their peers is mediated by children's behavioural patterns and competences.

\section{Method}

Participants

One hundred and sixty-three children participated in the study (94 boys and 69 girls). Children were interviewed in their first and second year of kindergarten. 
Mean age at first measurement is 5.19 years $(\mathrm{SD}=0.54)$ and at second measurement 6.17 years $(\mathrm{SD}=0.55)$.

Most children were recruited through their kindergarten classes. Sixteen kindergarten classes in the City of Basel (Switzerland) participated in the study. Kindergarten classes were selected from different city districts representing various socioeconomic and ethnic backgrounds representative of the City of Basel (Perren et al., 2006). After the kindergarten teacher had agreed to participate, parents were informed in a parent meeting and given written information on the study. Ninety-six families agreed to participate (participation rate $74 \%$ ). An additional 67 children are part of our longitudinal study on family relationships that began when the mothers of these children were pregnant (original $\mathrm{N}=80$, Perren et al., 2003). The two subsamples do not differ regarding the variables included in the current paper.

The participating families are mainly white, German-speaking, and of European origin. $23 \%$ children had at least one parent with foreign citizenship. Foreign citizenship and children's native language are highly associated, but the overlap is not absolute. Within the group of Swiss nationality $8 \%$ of children and within the foreign citizenship group $86 \%$ speak German as a second language. Participating children have a heterogeneous language background (e.g. Italian, Spanish, French, English, Bosnian, Turkish).

$52 \%$ of fathers ( $43 \%$ of mothers) have a university or vocational college degree; $19 \%$ of fathers ( $26 \%$ of mothers) have higher education, but without college degree; $20 \%$ of fathers (24\% of mothers) have a professional degree (vocational training); $9 \%$ of fathers ( $8 \%$ of mothers) only have basic education ( 9 years or less of schooling). Maternal and paternal education was combined to establish parental educational level (both parents only professional degree or lower: $N=39$; father or mother college degree or higher: $N=65$; both parents college or university degree: $N=59$ ).

\section{Procedure}

All children were interviewed individually in a separate room in their kindergarten or at home (depending on the recruitment scheme) by a trained psychologist. Teachers and parents completed questionnaires. Two assessments took place, in the first and second kindergarten year. Peer victimization was assessed by teacher and child report; children's difficulties were assessed by teacher, child and parent report; verbal ability was assessed by a standardized test; emotional family environment and sociodemographic information were obtained through parent report.

\section{Assessment of peer victimization}

Teachers rated each child on four victimization items (physical, verbal, object-related, exclusion; e.g. "child is victimized verbally») on a 5-point rating-scale (never, seldom, once or several times a month, once a week, or several times a week, $\alpha=.68)$ (Perren \& Alsaker, 2006). 
Children completed the Berkeley Puppet Interview to assess the frequency of peer victimization. The Berkeley Puppet Interview $(B P I)$, developed by Measelle et al. (1998) blends structured and clinical interviewing techniques to elicit children's self-perceptions (Perren, Stadelmann, Lüdin, von Wyl \& von Klitzing, 2008). The interview is carried out by means of two identical hand puppets that make two opposing statements on a topic, then the child can give his/her own statement. The interview is videotaped and afterwards scored by independent raters, who are blind to all other data. Each item is rated on a 7-point scale $(1-3=$ strong to mild agreement with the negative statement, $4=$ neither positive nor negative, 5-7 = mild to strong agreement with the positive statement). Our interviewers were trained by the authors of the instrument. Inter-rater reliability was first established with the authors of the instrument and second for the raters of the research group (average ICC $=.97)$. The scale (e.g. "Kids at school tease me») consists of four items $(\alpha=.70)$. We used the Swiss German translation of the items.

Teacher and child reports of victimization were also significantly associated $(\mathrm{r}=.33$ for age 5 and $\mathrm{r}=.24$ for age $6 ; \mathrm{p}<.01)$. For the victimization scale, the mean score of child and teacher reports were computed.

\section{Assessment of child characteristics}

Teacher and parent questionnaires. Parents and teachers completed the Strengths and Difficulties Questionnaire (SDQ, R. Goodman, 1997). Children's emotional/behavioural difficulties were assessed according to three scales: emotional symptoms, conduct problems and hyperactivity/impulsivity. Foreign-language speaking parents completed validated versions of the SDQ in their first language. Internal consistency was moderate to high (conduct problems: average Cronbach's $\alpha=.66$; hyperactivity/impulsivity: $\alpha=.80$; emotional symptoms: $\alpha=.71$ ).

Child interview. The BPI (see above) was also used to assess children's difficulties. To link child reports of behavioural/emotional difficulties with parent and teacher reports we aggregated the original BPI-subscales. The scales emotional symptoms encompasses depression, separation anxiety and over-anxiousness (e.g. «I am not a happy child», "I worry my mom or dad will go away and never come back», "I worry bad things are going to happen»; Average Cronbach's $\alpha=.73,20$ items). Conduct problems encompasses oppositionality/defiance and overt aggression to peers («When I get mad I lose my temper», I hit kids a lot'; $\alpha=.70,13$ items). The scale hyperactivity/impulsivity includes impulsivity plus a single item on inattention ("It's hard for me to wait my turn for things»; $\alpha=.52,7$ items). The BPI scales were reversed to parallel the meaning of the adults' scales.

Aggregation of multi-informant data. As recommended by Kraemer et al. (2003) we aggregated child, parent and teacher reports to assess children's difficulties. The concordance between children's and adults' ratings were in the expected range (teacher: $\mathrm{r}=.13-.23^{*}$; parents: $\mathrm{r}=.12-.15$ ), the correlation between parents and teacher $\left(\mathrm{r}=.28^{* *}-.52^{* *}\right)$ can be considered as being high (Kraemer 
et al., 2003). Previous analyses of the cross-sectional data (principal component analyses) showed that the aggregation of the three informants yielded reliable and valid information on children's symptoms (Perren et al., 2006). To combine child, parent and teacher reports on symptoms, the average scores of each informant were first $\mathrm{z}$-standardized and then averaged across informants (mean scores). The scores were built when information from at least two different informants was available.

Verbal ability. Children completed the Peabody Picture Vocabulary Test-R (Dunn \& Dunn, 1981). The PPVT-test assesses children's receptive vocabulary which we consider to be an indicator of their verbal ability. The test was delivered in Swiss German. As there is no validated version of the Swiss German translation of the test, all children completed a pre-defined number of items (57 items). Verbal ability was defined as the percentage of correct items.

\section{Assessment of family characteristics}

Emotional family environment. The quality of family relations was assessed by parent reports using the German version of the Family Environment Scale (Moos \& Moos, 1981; Schneewind, 1987). We used the subscales cohesion, expressiveness and conflict which assess the emotional climate within the family. The subscale cohesion describes the supportiveness shown by family members towards each other ( 6 items, $\alpha=.61$ ). The subscale expressiveness assesses the extent to which family members act openly and express their feelings ( 4 items; $\alpha=0.60$ ). The subscale conflict describes the amount of anger and aggression expressed in the family ( 8 items, $\alpha=.79$ ). Items are rated on a 4-point scale.

\section{Results}

First, we present descriptive results regarding stability of the main variables between the age of 5 and 6 and cross- sectional associations between child and family variables. Second, we present the results of GLM-analyses of child and family factors at age 5 predicting peer victimization at ages 5 and 6 (repeated measures). In a first step, child variables (gender, symptoms, and verbal ability) served as independent variables. In a second step, family variables (emotional family environment, parental educational status, foreign citizenship) served as independent variables. In a third step, child and family variables were entered simultaneously to analyze potential mediation effects.

\section{Stability and bivariate associations between child and family variables}

Stability. From the first to the second kindergarten year, peer victimization showed moderate stability: $r=.33^{* *}$. Symptoms were highly stable; all $r>.56$ (see Perren, Stadelmann, von Wyl \& von Klitzing, 2007). Parents also reported a mo- 
derate to high stability of family environment (cohesion: $\mathrm{r}=.64^{* *}$, conflicts: $\mathrm{r}=.68^{* *}$; expressiveness: $\left.\mathrm{r}=.48^{* *}\right)$. Verbal ability was also highly stable $\left(\mathrm{r}=.75^{* *}\right)$.

Next, we computed correlation analyses regarding child and family variables (cross-sectional associations, see Table 1).

Child variables. Conduct problems and hyperactivity/impulsivity were highly associated with each other and moderately associated with emotional symptoms. Verbal ability was negatively associated with hyperactivity (age 5 only). Males showed higher levels of conduct problems (age 5 and 6) and hyperactivity/impulsivity (age 6 only). Peer victimization was positively associated with symptoms (age 5 and 6) and negatively with verbal ability (age 5 only).

Family variables. Family conflicts were negatively associated with cohesion and expressiveness (age 6 only). Parental educational level was negatively associated with family cohesion and positively with expressiveness (age 6 only). Families with foreign citizenship indicated lower expressiveness. Parental educational level was significantly associated with peer victimization (age 6 only).

Family and child variables. Higher levels of family conflicts were associated with higher levels of conduct problems, hyperactivity/impulsivity (age 5 only), and emotional symptoms. Children from families with lower education or foreign citizenship showed more conduct problems, higher hyperactivity/impulsivity and had lower verbal abilities.

\section{Child variables at age 5 predicting peer victimization} The GLM-analyses (see Table 2 ) show that conduct problems significantly predicted peer victimization at both times $\left(\mathrm{B}_{\mathrm{t} 1}=0.313^{* *}, \mathrm{~B}_{\mathrm{t} 2}=0.236^{*}\right)$. Children showing higher levels of conduct problems were more frequently victimized by their peers. The significant within-subject effects shows that emotional symptoms also significantly predicted peer victimization, but only at age 5 $\left(\mathrm{B}_{\mathrm{t} 1}=0.308^{* *}\right)$ and not at age $6\left(\mathrm{~B}_{\mathrm{t} 2}=-0.075, \mathrm{~ns}\right)$. The effect of verbal ability was marginally significant, indicating that the lower children's verbal ability the higher their level of peer victimization $\left(\mathrm{B}_{\mathrm{t} 1}=-0.986^{*}, \mathrm{~B}_{\mathrm{t} 2}=-0.314, \mathrm{~ns}\right)$.

\section{Family variables at age 5 predicting peer victimization} The GLM-analyses regarding family variables yielded only a significant betweenand a marginally significant within-subject-effect of parental educational status (Table 2). Children from lower educated families were more frequently victimized by their peers than children from families with average or higher education. This difference was larger at age 6 than at age 5 (see Figure 1). None of the emotional family environment variables was significant.

\section{Child and family variables at age 5 predicting peer victimization}

In a next step, child and family variables were entered in the same analysis (see Table 2). The effects regarding child variables remained similar to the effects re- 
ported above (significant effects of conduct problems, emotional symptoms). The significant effect of parental educational level remained unchanged, and the within-subject effect of educational level now reached significance, i.e. children from lower educated families showed increases in peer victimization over time (see Figure 1). The effect of Time*Verbal ability was significant, indicating that the lower children's verbal ability the higher their level of peer victimization at age 5 , but not at age $6\left(B_{t 1}=-0.967^{*}, B_{t 2}=0.252\right.$, ns $)$.

In addition, family conflicts significantly predicted peer victimization $\left(B_{t 1}=-0.286^{*}, B_{t 2}=-0.190\right.$, ns $)$. This indicates that when controlling for child difficulties and educational status, higher levels of family conflicts predicted lower levels of peer victimization.

\section{Discussion}

\section{Children's behavioural and emotional difficulties and peer victimization}

As hypothesized, children's behavioural difficulties were significantly associated with peer victimization. The bivariate analyses indicated that children who show conduct problems and hyperactivity/impulsivity have an increased risk of victimization. This goes in line with other studies, which showed that ADHD-problems are prevalent among bully-victims (Alsaker \& Nägele, 2008; Holmberg \& Hjern, 2008). However, when controlled for each other, children's conduct problems but not hyperactivity/impulsivity significantly predicted peer victimization. Conduct problems and hyperactivity were highly associated. Maybe in kindergarten age, hyperactivity/impulsivity may be primarily an issue for the teacher who organizes structured learning opportunities, whereas for the peers aggressive and disruptive behaviour during free play may be more relevant (Perren et al., 2006).

The study also yielded significant associations between emotional symptoms and peer victimization. The bivariate analyses showed significant concurrent associations for both assessment points. However, in the multivariate analyses, emotional symptoms at age 5 were only associated with peer victimization at age 5 , but not at age 6 . This result might indicate that emotional symptoms are not a risk factor for peer victimization, but that peer victimization is leading to emotional symptoms. A wealth of studies shows that being a victim of bullying has negative short- and long-term consequences. Peer victimization and exclusion may also increase children's depressive symptoms (Gazelle \& Ladd, 2003; M. R. Goodman, Stormshak \& Dishion, 2001; Hanish \& Guerra, 2002). These longitudinal findings indicate that peer rejection and victimization may play a causal role in the development of depressive symptoms. In fact, in a recent twin study, the causal influence (mediating function) of peer victimization for depressive symptoms was confirmed (Arseneault et al., 2008). Based on the finding that be- 
havioural and emotional difficulties are quite strongly associated in this age group, we suggest that peer victimization should also be considered as a potential mediator between externalizing behaviour problems and emotional symptoms (see Perren, Groeben, Stadelmann \& von Klitzing, 2008).

\section{Emotional family environment and peer victimization}

In contrast to our expectations, children's family environment (conflicts, cohesion and expressiveness) was not associated with peer victimization. But this finding goes in line with a study by Veenstra et al. (2005) which neither found significant associations between peer victimization and parental rejection, overprotection and emotional warmth in the family. In the multivariate analysis, an unexpected result emerged. When controlling for children's difficulties and family background, high levels of family conflicts were associated with lower levels of peer victimization. Maybe experiencing and resolving familial conflicts increases children' ability to defend themselves, which may protect against peer victimization (Perren \& Alsaker, 2006; Perren, Groeben et al., 2008). However, as family conflicts are positively associated with conduct problems, it also might be that these children are becoming bullies (instead of victims or bully-victims). It is important to note that we did not assess severe family conflicts involving violence and child abuse, but rather families' tendency for having frequent conflicts and disagreements and solving them in a rather (negative) emotional way.

\section{Educational Level, foreign citizenship and children's verbal abilities as risk factors}

In contrast to the emotional family environment which seems to be unrelated to peer victimization, we found significant effects of the family background. Parental education emerged as a strong risk factor for peer victimization which impact is even getting stronger over time. Therefore, the kindergarten setting did not level out potential differences between children from low- and high-level income, but instead seems to reinforce these differences. Although children from lower educated families showed higher levels of difficulties and lower levels of verbal abilities, the effect of parental educational level was not mediated through child characteristics, but rather seems to be an overlapping risk factor or a proxy risk factor (Kraemer, Stice, Kazdin, Offord \& Kupfer, 2001). The question what mediating mechanisms lay between parents' low education and high level of peer victimization in kindergarten remains open. Further studies have to investigate whether processes of stereotyping, prejudices or discrimination from others are at work. It might also be that negative experiences within the family have an impact on children's representation of the self (e.g. a «victim schema» as weak and helpless) which then might invite peer victimization (Perry, Hodges \& Egan, 2001). It also might be that children from lower educated families lack certain social skills which render them at risk for being victims of peer aggression. 
In contrast to our expectations children from foreign language families did not have an increased risk of peer victimization, although they show higher levels of conduct problems and hyperactivity/impulsivity. However, we found a significant effect of children's deficits in verbal abilities on peer victimization. In our study children's verbal ability was assessed with a standardized test (PPTV, Dunn \& Dunn, 1981) which measures children's receptive vocabulary in Swiss German. Therefore, the test scores are a mixture of children local language competence and their verbal intelligence. The specific significance of children's local language competence was also demonstrated in another study in Swiss kindergartens which showed that the impact of parental immigrant background on children's victimization level is mediated through deficits in local language competence (von Grünigen et al., 2009).

In Switzerland, most children go the public school which belongs to their city district. Therefore, kindergarten groups and school classes differ regarding their mixture of socio-economic status (parental education, foreign citizenship). In classes consisting mainly of children from low-income and foreign-language families, the level of aggression is higher than in other groups. Therefore, children may have an increased risk of victimization which is not related to their individual and family characteristics but to their kindergarten or school environment. Our results suggest that the kindergarten setting may reinforce preexisting inequalities in health and problem behaviours.

\section{Implications for further research}

Our study applied a multi-informant approach and included not only parent and teacher reports but also children's self-perception. The Berkeley Puppet Interview (BPI) was used to assess children's self-perception of symptoms and peer victimization. As the integration of children's own perspective yields not only important additional information (Perren \& von Klitzing, 2008), but is a necessary element to assess the most valid and reliable data (Kraemer et al., 2003; Perren et al., 2006), the BPI should be used also in other studies to assess preschool and kindergarten children's symptoms and peer victimization.

Our findings suggest that low verbal ability is a risk factor for peer victimization. Further studies have to show whether this association can be explained by children's deficits in local language competence, in communication skills in social situations or more generally by deficits in children's verbal intelligence.

In the current study we adopted a dimensional approach to investigate risk factors for peer victimization, and we did not differentiate between different types of victims. However, other studies have suggested that there are two different pathways to victimization: (1) a pathway for aggressive victims, i.e. children who act aggressively against peers and seem to lack self-regulation skills and (2) a pathway for children who are victimized without being aggressive, and who show withdrawn-submissive behaviour patterns (passive victims) (e.g. Alsaker \& Nägele, 2008; Veenstra et al., 2005). Maybe this lack of differentiation between 
passive and aggressive victims hindered us to detect differential associations e.g. regarding aggressive and passive victims' family environment. Due to the rather small sample size, we only included gender as a control variable. However, some studies have shown that parental overprotection is only a risk factor for boys (Finnegan et al., 1998; Ladd \& Ladd, 1998). Further studies should thus analyse gender as a potential moderator. Moreover, we need more prospective studies to shed light on the role that family background play for peer victimization and bullying. There is also a need for more studies that measure a wide range of potential risk factors coming from multiple domains and starting before the establishment of (negative) peer relationships (Burk et al., 2008).

In our study we focussed on the impact of individual and family risk factors and we did not take into account the school context. As our sample was too small and too heterogeneous in terms of participants' nestedness within classrooms, we were not able to conduct multi-level analyses. Further studies should include more specifically the role of the classroom and school context.

\section{Educational and clinical implications}

The results reveal important implications for educational institutions regarding health promotion. First, the study indicates that children who already show behavioural difficulties at the beginning of kindergarten are at risk for becoming victims of bullying, which may subsequently lead to increases in their problems. Thus, the vicious circle of symptoms and negative peer relations (Hay et al., 2004) can be observed already in kindergarten age. As peer victimization is considered as a causal factor regarding depressive symptoms, the prevention of bully/victim problems in kindergarten and schools (Alsaker \& Valkanover, 2001; Smith, Pepler \& Rigby, 2004) should be considered as an important and effective measure against children's mental health problems. In addition, studies in school age children have shown that peer victimization may impair children's motivation and capacity to learn, and may increase their school avoidance and even leads to academic difficulties (Graham et al., 2006; Nishina et al., 2005). Likewise studies in kindergarten age have shown that peer victimization predict later school avoidance (Kochenderfer \& Ladd, 1996). As kindergarten is the entry gate into the formal education system, we might even assume that negative social experiences during this developmental period may have lasting effects on children's academic motivation and achievement. Therefore, the prevention of bullying becomes an important educational task for teachers, kindergartens and schools.

Second, the study emphasizes the role of children's verbal abilities. Although the instrument we used to assess children's verbal abilities (PVVT) assesses receptive vocabulary and is not designed as an instrument to assess children's local language competence, we assume that these competences are highly related. Having parents with a foreign citizenship is not a risk factor per se, but having deficits in (Swiss) German is a risk factor for being victimized. As the impact of low 
verbal ability was only shown in the first kindergarten year, learning the local language before entering kindergarten may protect children from negative experiences. In fact, Swiss studies have shown that attending daycare centers or preschool programs increases foreign language preschool children's chance for a successful transition to school (Lanfranchi, 2002; Schultheis, Perrig-Chiello \& Egger, 2008).

Third, the significance of parental educational status was also shown. Even when controlling for children's difficulties, language abilities and family conflicts, families' socio-economic status remained a significant predictor for peer victimization. The study results emphasize the importance of early prevention efforts in families from lower socio-economic backgrounds: for example programmers with start in toddler age (e.g. Opstapje; see www.a-primo.ch; Sann \& Thrum, 2003). or even in the prenatal period (Pro Kind; http://www.stiftungpro-kind.de; Jungmann, Kurtz \& Brand, 2008). Such early intervention strategies assumingly would not only support children's transition to kindergarten and school on the academic level, but also regarding their integration in the peer group.

Our study has shown that certain children are vulnerable to becoming victims of bullying. However, from a social-ecological view the emergence and maintenance of bullying is strongly influenced by the social context (Pepler et al., 1999). Therefore, in addition to taking specific measures against bullying (Alsaker \& Valkanover, 2001), teaching tolerance and respect towards persons who are "different» (regarding their language, assets, skills, appearance) might also an important step towards a positive school climate in kindergartens and schools. 


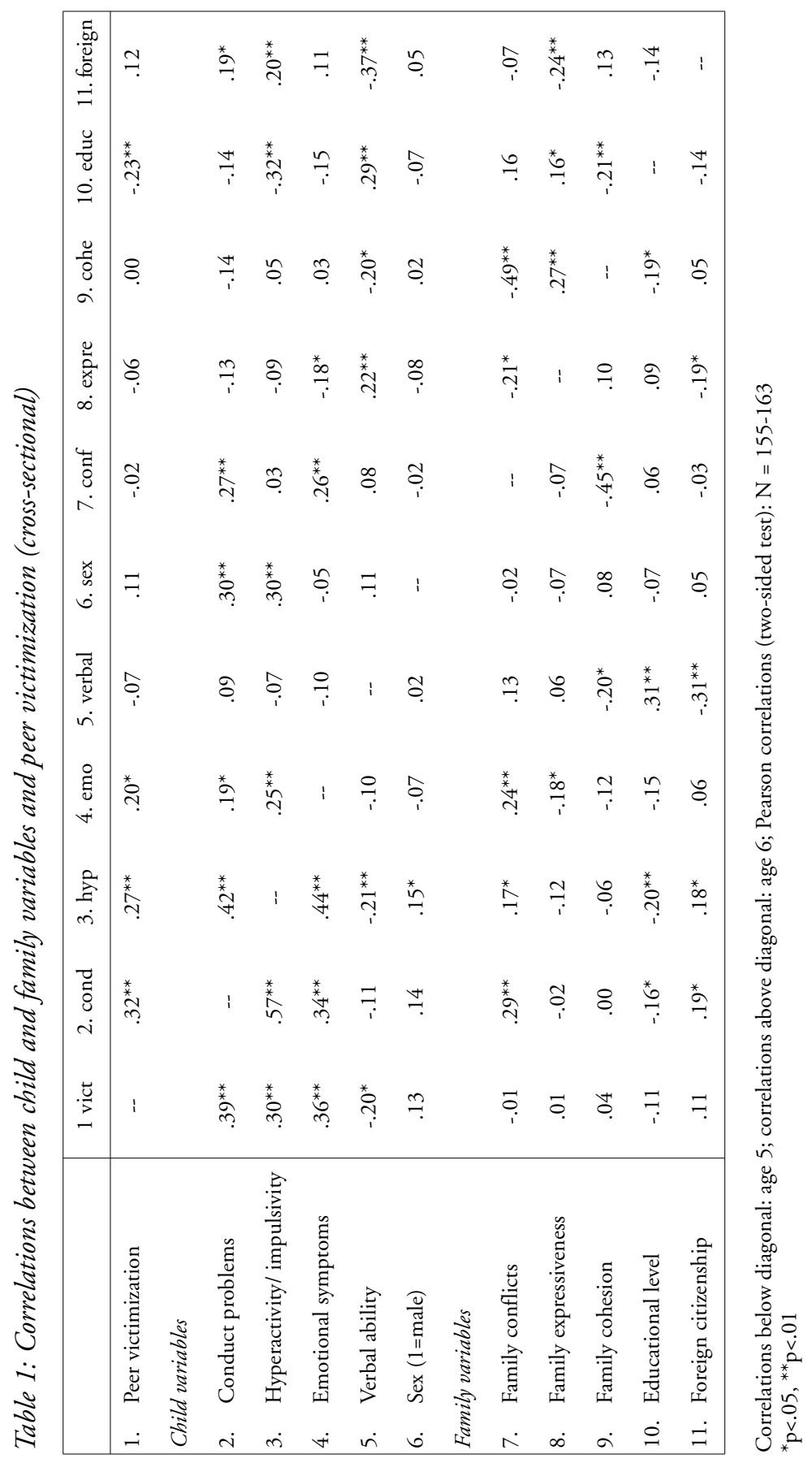


Table 2: Child andlor family variables (age 5) predicting peer victimization (age 5 and age 6)

\begin{tabular}{|lccc|}
\hline Variables & $\begin{array}{c}\text { M1: Child } \\
(\mathrm{N}=156)\end{array}$ & $\begin{array}{c}\text { M2: Family } \\
(\mathrm{N}=149)\end{array}$ & $\begin{array}{c}\text { M3: Child \& } \\
\text { Family (N=144) }\end{array}$ \\
\hline Between-subject effects & 2.31 & -- & 2.56 \\
Child sex & $12.12^{* *}$ & -- & $15.68^{* *}$ \\
Conduct problems & 0.18 & -- & 0.02 \\
Hyperactivity/impulsivity & 2.56 & -- & $4.01^{*}$ \\
Emotional symptoms & $3.22^{*}$ & -- & 0.81 \\
Verbal ability & -- & $4.89^{* *}$ & $4.11^{*}$ \\
Educational level & -- & 1.56 & 0.01 \\
Foreign citizenship & -- & 0.01 & $4.18^{*}$ \\
Conflicts & -- & 0.01 & 1.65 \\
Expressiveness & -- & 0.91 & 0.60 \\
Cohesion & & & \\
\hline Within-subject effects & 1.52 & 0.00 & 0.74 \\
Time & 0.64 & -- & 0.40 \\
Time ${ }^{*}$ Sex & 0.42 & -- & 0.77 \\
Time ${ }^{*}$ Conduct problems & 1.31 & -- & 1.00 \\
Time * Hyperactivity/ impulsivity & $12.05^{* *}$ & -- & $14.13^{* *}$ \\
Time ${ }^{*}$ Emotional symptoms & 1.50 & -- & $4.10^{*}$ \\
Time ${ }^{*}$ Verbal ability & -- & $2.69^{*}$ & $4.89^{* *}$ \\
Time ${ }^{*}$ Educational level & -- & 0.04 & 0.18 \\
Time ${ }^{*}$ Foreign citizenship & -- & 0.11 & 0.30 \\
Time ${ }^{*}$ Conflicts & -- & 0.09 & 0.00 \\
Time ${ }^{*}$ Expressiveness & -- & 0.22 & 0.00 \\
Time ${ }^{*}$ Cohesion & & &
\end{tabular}

Cells show F-values; ${ }^{*} \mathrm{p}<.05,{ }^{* *} \mathrm{p}<.01$

Figure 1: Peer victimization (age 5 and age 6) by parental educational level

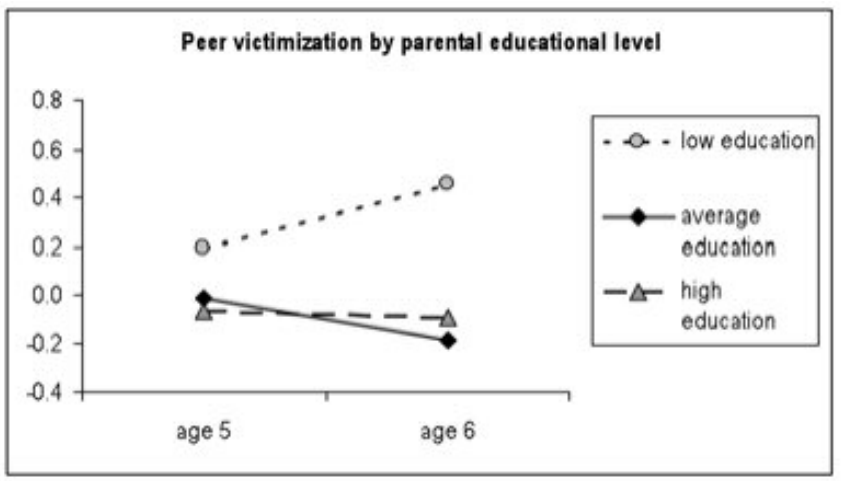




\section{References}

Alsaker, F. \& Nägele, C. (2008). Vulnerability to victimization: Need for differentiation between pure victims and bully-victims in kindergarten. Manuscript submitted for publication.

Alsaker, F. \& Valkanover, S. (2001). Early diagnosis and prevention of victimization in kindergarten. In J. Juvonen \& S. Graham (Eds.), Peer harassment in school: The plight of the vulnerable and victimized (pp. 175-195). New York: Guilford Press.

Arseneault, L., Milne, B. J., Taylor, A., Adams, F., Delgado, K., Caspi, A., et al. (2008). Being bullied as an environmentally mediated contributing factor to children's internalizing problems. Archives of Paediatric and Adolecent Medicine, 162, 145-150.

Bowers, L., Smith, P. K. \& Binney, V. (1992). Cohesion and power in the families of children involved in bully/victim problems at school. Journal of Family Therapy, 14 (4), 371-187.

Bowers, L., Smith, P. K. \& Binney, V. (1994). Perceived family relationships of bullies, victims and bully/victims in middle childhood. Journal of Social and Personal Relationships, 11 (2), 215-232.

Burk, L. R., Park, J. h., Armstrong, J. M., Klein, M. H., Goldsmith, H. H., Zahn Waxler, C., et al. (2008). Identification of early child and family risk factors for aggressive victim status in first grade. Journal of Abnormal Child Psychology, 36 (4), 513-526.

Coie, J. D., Dodge, K. A. \& Kupersmith, J. B. (1990). Peer group behavior and social status. In S. R. Asher \& Coie, J. D. (Ed.), Peer rejection in childhood (pp. 17-57). Cambrigde: University.

Deater-Deckard, K. (2001). Annotation: Recent research examining the role of peer relationships in the development of psychopathology. Journal of Child Psychology and Psychiatry and Allied Disciplines, 42, 565-579.

Dunn, L. M. \& Dunn, L. M. (1981). Peabody picture vocabulary test-Revised. Circle Pines, $\mathrm{MN}$ : American Guidance Service.

Eckhart, M. (2005). Anerkennung und Ablehnung in Schulklassen: Einstellungen und Beziehungen von Schweizer Kindern und Immigrantenkindern. Bern: Haupt.

Espelage, D. L., Bosworth, K. \& Simon, T. R. (2000). Examining the social context of bullying behaviors in early adolescence. Journal of Counseling and Development, 78 (3), 326-333.

Espelage, D. L. \& Swearer, S. (Ed.). (2004). Bullying in American schools: A social ecological perspective on prevention and intervention. Mahwah, NJ: Erlbaum Publishers.

Finnegan, R. A., Hodges, E. V. E. \& Perry, D. G. (1998). Victimization by peers: Associations with children's reports of mother-child interaction. Journal of Personality and Social Psychology, 75 (4), 1076-1086.

Gazelle, H. \& Ladd, G. W. (2003). Anxious solitude and peer exclusion: A diathesis-stress model of internalizing trajectories in childhood. Child Development, 74 (1), 257-278.

Goodman, M. R., Stormshak, E. A. \& Dishion, T. J. (2001). The significance of peer victimization at two points in development. Journal of Applied Developmental Psychology, 22 (5), 507-526.

Goodman, R. (1997). The Strengths and Difficulties Questionnaire: A Research Note. Journal of Child Psychology and Psychiatry and Allied Disciplines, 38, 581-586.

Graham, S., Bellmore, A. D. \& Mize, J. (2006). Peer Victimization, Aggression, and Their Co-Occurrence in Middle School: Pathways to Adjustment Problems. Journal of Abnormal Child Psychology, 34 (3), 363378.

Hanish, L. D. \& Guerra, N. G. (2002). A longitudinal analysis of patterns of adjustment following peer victimization. Development and Psychopathology, 14 (1), 69-89.

Hanish, L. D. \& Guerra, N. G. (2004). Aggressive victims, passive victims, and bullies: Developmental continuity and developmental change? Merrill-Palmer Quarterly, 50 (1), $17-$ 38.

Hay, D. F., Payne, A. \& Chadwick, A. (2004). Peer relations in childhood. Journal of Child Psychology and Psychiatry and Allied Disciplines, 45 (1), 84-108. 
Henricsson, L. \& Rydell, A. M. (2004). Elementary school children with behavior problems: Teacher-child relations and self-perception. A prospective study. Merrill Palmer Quarterly, 50 (2), 111-138.

Hodges, E. V. E., Malone, M. J. \& Perry, D. G. (1997). Individual risk and social risk as interacting determinants of victimization in the peer group. Developmental Psychology, 33 (6), 1032-1039.

Hodges, E. V. E. \& Perry, D. G. (1999). Personal and interpersonal antecedents and consequences of victimization by peers. Journal of Personality and Social Psychology, 76 (4), 677685.

Holmberg, K. \& Hjern, A. (2008). Bullying and attention-deficit-hyperactivity disorder in 10-year-olds in a Swedish community. Developmental Medicine and Child Neurology, 50 (2), 134-138.

Jungmann, T., Kurtz, V. \& Brand, T. (2008). Das Modellprojekt «Pro Kind» - Eine Verortung in der Landschaft früher Hilfen. Frühförderung Interdisziplinär, 2, 67-78.

Kochenderfer, B. J. \& Ladd, G. W. (1996). Peer victimization: Cause or consequence of school maladjustment? Child Development, 67 (4), 1305-1317.

Kraemer, H., Measelle, J. R., Ablow, J. C., Essex, M. J., Boyce, W. T. \& Kupfer, D. J. (2003). A new approach to integrating data from multiple informants in psychiatric assessment and research: Mixing and matching contexts and perspectives. American Journal of Psychiatry, 160, 1566-1577.

Kraemer, H., Stice, E., Kazdin, A., Offord, D. R. \& Kupfer, M. D. (2001). How do risk factors work together? Mediators, moderators, and independent, overlapping, and proxy risk factors. American Journal of Psychiatry, 158, 848-856.

Kronig, W., Haeberlin, U. \& Eckhart, M. (2000). Immigrantenkinder und schulische Selektion. Pädogagische Visionen, theoretische Erklärungen und empirische Untersuchungen zur Wirkung integrierender und separierender Schulformen in den Grundschuljahren. Bern: Haupt.

Ladd, G. W. \& Burgess, K. B. (1999). Charting the relationship trajectories of aggressive, withdrawn, and aggressive/withdrawn children during early grade school. Child Development, 70 (4), 910-929.

Ladd, G. W. \& Ladd, B. K. (1998). Parenting behaviors and parent-child relationships: Correlates of peer victimization in kindergarten? Developmental Psychology, 34 (6), 1450-1458.

Lanfranchi, A. (2002). Schulerfolg von Migrationskindern. Die Bedeutung familienergänzender Betreuung im Vorschulalter. Opladen: Leske \& Budrich.

Measelle, J. R., Ablow, J. C., Cowan, P. A. \& Cowan, C. P. (1998). Assessing young children's views of their academic, social, and emotional lives: An evaluation of the self-perception scales of the Berkeley Puppet Interview. Child Development, 69, 1556-1576.

Mohr, A. (2006). Family variables associated with peer victimization: Does family violence enhance the probability of being victimized by peers? Swiss Journal of Psychology/Schweizerische Zeitschrift für Psychologie/Revue Suisse de Psychologie, 65 (2), 107-116.

Moos, R. H. \& Moos, B. S. (1981). Family Environment Scale. Manual. Palo Alto.: Consulting Psychologists.

Nishina, A., Juvonen, J. \& Witkow, M. R. (2005). Sticks and Stones May Break My Bones, but Names Will Make Me Feel Sick: The Psychosocial, Somatic, and Scholastic Consequences of Peer Harassment. Journal of Clinical Child and Adolescent Psychology, 34 (1), 37 48.

Olweus, D. (1991). Bully/victim problems among schoolchildren. Basic facts of a school based intervention program. In D. J. Pepler \& K. H. Rubin (Eds.), The development and treatment of childhood aggression (pp. XVII, 470). Hillsdale (N.J.) [etc]: Lawrence Erlbaum.

Parke, R. D. \& Ladd, G. W. (1992). Family-peer relationships. Modes of linkages. Hillsdale, N.J.: Lawrence Erlbaum.

Pepler, D., Craig, W. M. \& O’Connell, P. (1999). Understanding bullying from a dynamic 
systems perspective. In A. Slater \& D. Muir (Ed.), The Blackwell reader in development psychology (pp. 440-451). Malden, MA: Blackwell Publishers.

Perren, S. \& Alsaker, F. D. (2006). Social behavior and peer relationships of victims, bully-victims, and bullies in kindergarten. Journal of Child Psychology and Psychiatry, 47 (1), 45-57.

Perren, S., Groeben, M., Stadelmann, S. \& von Klitzing, K. (2008). Selbst- und fremdbezogene soziale Kompetenzen: Auswirkungen auf das emotionale Befinden. In T. Malti \& S. Perren (Ed.), Soziale Kompetenz bei Kindern und Jugendlichen: Entwicklungsprozesse und Förderungsmöglichkeiten. Stuttgart: Kohlhammer.

Perren, S., Stadelmann, S., Lüdin, J., von Wyl, A. \& von Klitzing, K. (2008). Kindergartenkinder schätzen ihre Symptome und Stärken ein: Das Berkeley Puppet Interview in Forschung und Praxis. Kinderanalyse, 16 (1), 1-22.

Perren, S., Stadelmann, S., von Wyl, A. \& von Klitzing, K. (2007). Developmental pathways of emotional/behavioural symptoms in kindergarten children: What is the role of pro-social behaviour? European Child and Adolescent Psychiatry, 16 (4), 209-214.

Perren, S. \& von Klitzing, K. (2008). Untersuchung von Kindergartenkindern mit einem Puppeninterview: Bedeutsamkeit und Anwendung. Kinder- und Jugendmedizin (Schwerpunktheft: Kinder- und Jugendpsychiatrie), 8 (1), 25-30.

Perren, S., Von Wyl, A., Simoni, H., Stadlmayr, W., Bürgin, D. \& Von Klitzing, K. (2003). Parental psychopathology, marital quality, and the transition to parenthood. American Journal of Orthopsychiatry, 73 (1), 55-64.

Perren, S., Von Wyl, A., Stadelmann, S., Burgin, D. \& von Klitzing, K. (2006). Associations between behavioral/emotional difficulties in kindergarten children and the quality of their peer relationships. Journal of the American Academy of Child and Adolescent Psychiatry, 45 (7), 867-876.

Perry, D. G., Hodges, E. V. E. \& Egan, S. K. (2001). Determinants of chronic victimization by peers: A review and new model of family influence. In J. Juvonen \& S. Graham (Eds.), Peer harassment in school: The plight of the vulnerable and victimized (pp. 73-104). New York, NY: Guilford Press.

Quintana, S. M., Chao, R. K., Cross Jr., W. E., Hughes, D., Nelson-Le Gall, S., Aboud, F. E., et al. (2006). Race, ethnicity, and culture in child development: Contemporary research and future directions. Child Development, 77 (5), 1129-1141.

Ridder, A. \& Dollase, R. (1999). Interkulturelle Integration bei Hauptschülern im Zeitvergleich 1983-1996. In R. Dollase, T. Kliche \& H. Moser (Eds.), Politische Psychologie der Fremdenfeindlichkeit: Opfer - Täter-Mittäter (pp. 219-240). Weinheim: Juventa.

Rigby, K. (1993). School children's perceptions of their families and parents as a function of peer relations. Journal of Genetic Psychology, 154 (4), 501-513.

Rudolph, K. D. \& Clark, A. G. (2001). Conceptions of relationships in children with depressive and aggressive symptoms: Social-cognitive distortion or reality? Journal of Abnormal Child Psychology, 29 (1), 41-56.

Sann, A. \& Thrum, K. (2003). Perspektiven präventiver Frühförderung im Kontext sozialer Benachteiligung. Das präventive Frühförderprogramm „Opstapje - Schritt für Schritt“ für Familien mit zwei- bis vierjährigen Kindern im wissenschaftlich begleiteten Ersteinsatz in der BRD. In I. I. f. s. Arbeit (Ed.), Beiträge zum ISA Kongress (pp. 77-83).

Schneewind, K. A. (1987). Die Familienklimaskalen (FKS). In M. Cierpka (Ed.), Familiendiagnostik (pp. 232-255). Berlin: Springer.

Schultheis, F., Perrig-Chiello, P. \& Egger, S. (2008). Kindheit und Jugend in der Schweiz. Weinheim: Beltz.

Schwartz, D., Dodge, K. A., Pettit, G. S. \& Bates, J. E. (1997). The early socialization of aggressive victims of bullying. Child Development, 68 (4), 665-675.

Smith, P. K., Pepler, D. \& Rigby, K. (Eds.). (2004). Bullying in schools: How successful can interventions be? (Vol. Cambridge University Press): New York.

Stevens, V., De Bourdeaudhuij, I. \& Van Oost, P. (2002). Relationship of the family environ- 
ment to children's involvement in bully/victim problems at school. Journal of Youth and Adolescence, 31 (6), 419-428.

Veenstra, R., Lindenberg, S., Oldehinkel, A. J., De Winter, A. F., Verhulst, F. C. \& Ormel, J. (2005). Bullying and Victimization in Elementary Schools: A Comparison of Bullies, Victims, Bully/Victims, and Uninvolved Preadolescents. Developmental Psychology., 41 (4), 672-682.

Verkuyten, M. (2006). Ethnic peer victimization and psychological well-being among early adolescents. In X. Chen, D. C. French \& B. H. Schneider (Eds.), Peer Relationships in Cultural Context (pp. 339-363). Cambridge: Cambridge University Press.

von Grünigen, R., Perren, S., Nägele, C. \& Alsaker, F. (2009).Immigrant children's peer acceptance and victimization in kindergarten: the role of local language competence, British Journal of Developmental Psychology, in press.

von Rueden, U., Gosch, A., Rajmil, L., Bisegger, C., Ravens Sieberer, U. \& European KIDSCREEN group. (2006). Socioeconomic determinants of health related quality of life in childhood and adolescence: Results from a European study. Journal of Epidemiology and Community Health, 60 (2), 130-135.

Wolke, D., Woods, S., Stanford, K. \& Schulz, H. (2001). Bullying and victimization of primary school children in England and Germany: Prevalence and school factors. British Journal of Psychology, 92 (4), 673-696.

Key words: peer victimization, emotional/behavioural difficulties, verbal ability, parental educational level, immigration background, family relationships, kindergarten

\section{Eigenschaften des Kindes und der Familie als Risikofaktoren für die Viktimisierung durch Gleichaltrige im Kindergarten}

\section{Zusammenfassung}

Die vorliegende Studie untersucht Risikofaktoren für die Viktimisierung durch Gleichaltrige. Es wird insbesondere untersucht, ob der Einfluss von Risikofaktoren auf der Ebene des Kindes (Verhaltensauffälligkeiten, verbale Kompetenz) den Einfluss von familiären Risikofaktoren (Familienklima, Bildungsstand der Eltern, Migrationshintergrund) mediiert. Eltern und Lehrpersonen füllten Fragebogen aus; mit den Kindern im Alter von 5 und 6 Jahren $(\mathrm{N}=163)$ wurden das Berkeley Puppeninterview und ein Sprachtest durchgeführt. Die Analysen zeigen, dass Risikofaktoren von Kind und Familie unabhängig voneinander wirken: Je mehr Verhaltensprobleme, je mehr emotionale Symptome und je schwächer die verbalen Fertigkeiten des Kindes, umso mehr Mobbingerfahrungen macht das Kind. Kinder aus bildungsfernen Familien haben ein erhöhtes Risiko Opfer zu werden. Pädagogische und klinische Implikationen werden diskutiert.

Schlüsselwörter: Mobbing, Verhaltensauffälligkeiten, verbale Kompetenz, Bildungsstand der Eltern, Migrationshintergrund, Familienbeziehungen, Kindergarten 


\section{Les caractéristiques individuelles et familiales comme facteurs de risque de victimisation par les pairs à l'école enfantine}

\section{Résumé}

La présente étude examine si les difficultés de l'enfant (symptômes, habiletés verbales) jouent un rôle médiateur dans la relation entre les variables familiales (l'environnement émotionnel dans la famille, le niveau d'éducation parentale et la citoyenneté étrangère) et la victimisation par les pairs. Les enseignants et les parents ont complété des questionnaires, les enfants entre 5 et 6 ans $(\mathrm{N}=163)$ ont complété le Berkeley Puppet Interview et un test d'habiletés verbales. Les résultats montrent que les caractéristiques individuelles et familiales, indépendamment les unes des autres, contribuent à prédire la victimisation par les pairs. Plus le degré de problèmes comportementaux et de symptômes émotionnels est élevé et plus les habiletés verbales de l'enfant sont faibles, plus la fréquence des expériences de victimisation est élevée. Les enfants issus de familles dont les parents sont peu scolarisés présentent un risque plus important de victimisation. Les résultats sont discutés sous l'angle des implications éducatives et cliniques.

Mots clés: victimisation par les pairs, problèmes de comportement, symptômes émotionnels, habiletés verbales, éducation parentale, enfants issus de l'immigration, l'école enfantine

\section{Caratteristiche infantili e famigliari come fattori di rischio di vittimizzazione tra pari alla scuola dell'infanzia}

\section{Riassunto}

Il presente studio investiga se le difficoltà dei bambini (sintomi, abilità verbale) mediano l'impatto delle variabili famigliari (ambiente famigliare, livello di formazione, cittadinanza straniera) sulla vittimizzazione tra pari. I maestri e i genitori hanno compilato dei questionari; i bambini hanno compilato il Berkeley Puppet Interview e un test d'abilità verbale all'età di 5 e 6 anni $(\mathrm{N}=163)$. Le analisi hanno rivelato che le caratteristiche infantili e famigliari contribuiscono in modo indipendente le une dalle altre a predire la vittimizzazione tra pari. Più é alto il livello di problemi di condotta e di sintomi emozionali e più è bassa l'abilità verbale dei bambini, più risulta alta la frequenza di esperienze di vittimizzazione. Bambini provenienti da famiglie con genitori di bassa formazione hanno un maggior rischio di vittimizzazione. I risultati vengono discussi alla luce delle implicazioni educative e cliniche.

Parole chiave: vittimizzazione tra pari, problemi di condotta e di sintomi emozionali, abilità verbale, ambiente famigliare, livello di formazione, cittadinanza straniera, scuola dell'infanzia 